\title{
Sustainable Transport: BRT experiences from Mexico and India
}

\author{
Rogat, Jorge; Dhar, Subash; Joshi, Rutul; Mahadevia, Darshini ; Mendoza, Juan Carlos
}

Published in:

Wiley Interdisciplinary Reviews: Energy and Environment

Link to article, DOI:

10.1002/wene. 162

Publication date:

2015

Document Version

Peer reviewed version

Link back to DTU Orbit

Citation (APA):

Rogat, J., Dhar, S., Joshi, R., Mahadevia, D., \& Mendoza, J. C. (2015). Sustainable Transport: BRT experiences from Mexico and India. Wiley Interdisciplinary Reviews: Energy and Environment, 4(6), 564-574.

https://doi.org/10.1002/wene.162

\section{General rights}

Copyright and moral rights for the publications made accessible in the public portal are retained by the authors and/or other copyright owners and it is a condition of accessing publications that users recognise and abide by the legal requirements associated with these rights.

- Users may download and print one copy of any publication from the public portal for the purpose of private study or research.

- You may not further distribute the material or use it for any profit-making activity or commercial gain

- You may freely distribute the URL identifying the publication in the public portal

If you believe that this document breaches copyright please contact us providing details, and we will remove access to the work immediately and investigate your claim 


\title{
Sustainable Transport: BRT experiences from Mexico and India
}

\author{
Jorge Rogat ${ }^{1}$ \\ Subash Dhar ${ }^{1}$ \\ Rutul Joshi ${ }^{2}$ \\ Darshini Mahadevia ${ }^{2}$ \\ Juan Carlos Mendoza ${ }^{3}$
}

\begin{abstract}
Increasing population and urbanisation is creating a steadily increasing demand for transport in the cities of many developing countries, coinciding with rapid economic growth leading to increasing demand for higher standards of living and faster and more efficient modes of transport. The decisions made today regarding transport infrastructure will affect long-term travel behaviour, with corresponding impacts on the economy, society and the environment, the last impact being one of the most important in times of steadily rising environmental concern. The successful experiences of Curitiba in Brazil and Bogotá in Colombia have served as a source of inspiration for other cities in Latin America and elsewhere. In 1973 Curitiba became the first city in the world to introduce an integrated land use and transport infrastructure approach with an integrated transport network based on bus rapid transit (BRT). The BRT systems of Curitiba and Bogotá have subsequently been adopted all over the world with some variations. Implementation of two recent BRTs, Mexico City and Ahmedabad in India, are examined in this paper.
\end{abstract}

\section{Introduction}

The transport sector accounted for approximately 22\% of world $\mathrm{CO}_{2}$ emissions in 2011 (IEA, 2013). According to estimates made by UN DESA, world population is expected to surpass 9 billion by 2050. Of this figure, around 6.3 billion will be living in urban areas, and most of the increase will be in developing regions (UN DESA, 2010). Coupled with rapid urbanization and increased mobility with private automobiles, transport-related emissions from urban areas are set to increase significantly. To come to grips with this development, more sustainable public transport systems need to be adopted.

A sustainable transport system can be defined as one that allows the basic access and development needs of individuals, companies and society more generally to be met safely and in a manner consistent with human and ecosystem health. It should promote equity within and between successive generations, operate fairly and efficiently, offer a choice of transport modes and support a competitive economy. It should also encourage balanced regional development, limit emissions and waste to the planet's ability to absorb them, use renewable resources at or below their rates of generation, and use non-renewable

\footnotetext{
${ }^{1}$ UNEP Risoe Centre, DTU. Roskilde, Denmark.

${ }^{2}$ CEPT University. Ahmedabad, India.

${ }^{3}$ Instituto Jose María Luis Mora, Mexico.
} 
resources at or below the rates of the development of renewable substitutes, while minimizing the impact on land use and noise generation (European Council of Ministries of Transport [ECMT], 2004). Simply put, sustainable transport options provide for intra- as well as inter-generational equity in access, while supporting economic growth in environmentally sustainable ways. Intra-generational equity deals with equity issues within development planning processes (George, 1999). This includes examining how the development will benefit all groups and individuals, including women.

Sustainable transport solutions can be categorized into three main areas (Dalkman et al., 2007):

- Transport avoidance: through proper land-use and transport planning, which can decrease the demand for mobility while increasing accessibility;

- Shifting to more sustainable modes: promoting use of low carbon mobility by influencing decisions on mobility options that are more sustainable by creating facilities for public transportation, walking, and cycling;

- Transport efficiency: through the deployment of technologies, driving behaviour and standards on fuel efficiency.

Bus Rapid Transit (BRT), is one such effective sustainable transport solution that can encourage shifts from private motor vehicles to the public transit system. BRT is also a way of providing high quality and capacity transport services in order to build a sustainable transport-based future. However, it should be clear that there are a series of barriers that need to be overcome before making a BRT implementation feasible and successful. These include economic barriers like capital investment (the upfront investment required is considerable and often not available), political barriers (the political will in current administration is crucial to promoting and facilitating implementation of BRT), and technical barriers (not having the required knowhow in place makes the implementation of a BRT system very difficult or doomed to fail).

This paper examines two relatively recent experiences of BRT, namely Metrobus in Mexico City and Janmarg in Ahmedabad, India which were perceived as successful implementations. Metrobus received in 2013 the Sustainable Transport Award from the Institute for Transportation and Development Policy (ITDP). It was also one of the first public transportation projects in the world to be granted the ability to offset credits for greenhouse gas emissions, these two being the main reasons for choosing Metrobus to be showcased. The Janmarg BRT in Ahmedabad was similarly recognised by ITDP and Ministry of Urban Development as a successful BRT project In addition these two cities are relatively recent BRT implementations and therefore provide a new context that makes them worth studying. The paper presents their features, implementation methodologies, costs, and economic, social and environmental benefits. Since both BRT systems have been recently implemented, the information available is quite limited. As a result, some of the comparisons made here are based on estimates.

\section{Features and benefits of BRT Systems}

Bus Rapid Transit (BRT) is a system that emphasizes priority for the rapid movement of buses (Wright, 2002) through ensuring priority for buses within the road space. The Curitiba and Bogotá BRTs have achieved this objective with the aid of the following design features: operating the buses along dedicated lanes, and introducing exclusive stations and off-board fare collection. These features are similar to rail systems such as metro, light-rail trains and trams, but at lower costs than the former two. Other features of 
BRT systems include the use of articulated buses with a carrying capacity of between 150 and 185 passengers, or bi-articulated buses with a carrying capacity of around 270 passengers, as well as interchange terminals and control centres from which the whole system can be permanently monitored. The buses are supplemented by feeder buses which carry passengers to interchange terminals. Modal integration is another feature of BRT systems, which in some cases complement rail-based metro systems, with feeder buses connecting both BRT and metro. Walking and cycling networks along BRT corridors and beyond to prioritise non-motorised transport (NMT) users in the city has been incorporated into some Latin American cities like Curitiba and Bogotá, which treat the NMT infrastructure as an integral part of the BRT system. Many existing BRT systems, as is the case of Latin America, are managed through a public-private partnership, where the government funds the required infrastructure, while private bus operators provide the buses under the regulatory framework set by the government or the corresponding transport authority. Most of the BRT systems implemented in Latin America are not subsidised, yet despite relatively low fares are financially sustainable (Rogat, J., Hinostroza, M., Ernest, K., 2009)..

BRT systems have brought considerable benefits to the cities where these systems have been implemented. ${ }^{4}$ Before BRT implementation, these cities were characterised by high levels of congestion, large numbers of traffic accidents and severe air contamination. This was, to a large extent, the result of inefficient and poorly managed public transport services that were unable to meet the increasing demand for transportation, thus promoting the switch away from public to private motorised transportation. The answer to this dilemma was to find a new transport paradigm such as the BRT system. By relying on the concept of moving people rather than cars, the BRT system has challenged cultural and class barriers to inclusive transport in cities and brought significant benefits for their environment, the economy and society. Mass rapid transit (MRT) systems use high-capacity articulated buses running on cleaner fuel that can each replace four or five conventional buses. This in itself means a significant reduction in fuel consumption, and thus in levels of emissions. In addition, these buses are using improved fuel efficient technology. ${ }^{5}$ Consequently, for example, the BRT system of Curitiba has resulted in a $25 \%$ reduction in fuel consumption and concomitant emission reductions (Rogat, et al., 2007). BRT implementations often require, and are therefore normally coupled with, comprehensive restructuring of the transport sector, which indirectly brings a series of environmental benefits. For instance, the restructuring usually involves the construction of bikeways along BRT corridors that further promoting and facilitating changes in transport mode. For example, in the case of TransMilenio, around 400 kilometres of bikeways were constructed in the city of Bogotá, increasingly validating bicycle use as a mode of transportation. Another measure that has been included in these transport-sector reforms is the introduction of car-free days, where private cars are banned from the city centre. A modal change, particularly from motorised to nonmotorised transportation, is directly reflected in the positive impacts on the environment (because of less pollution), the economy (because of decreased congestion) and society (because of improved health due to cycling). In addition, improved bikeways also protect no-choice cyclists, that is, those who cannot do anything except cycling for mobility, thus including the poor in road design.

BRT systems are low cost compared to other MRT systems like Metros. The Latin American experience shows that BRT systems have been delivered at a cost of between US $\$ 1$ million and US\$5.3 million per

\footnotetext{
${ }^{4}$ BRT systems have been implemented in 146 cities around the world. www.brtdata.org

${ }^{5}$ The TransMilenio system has reported some pollutant levels for 2000 and 2001 from a monitoring station close to Av. Caracas Busway. It showed a reduction of $43 \%$ in sulfur dioxide, $18 \%$ in nitrogen dioxide and $12 \%$ in particulate matter (less than 10 micras) (Sandoval, 2005).
} 
kilometre, compared to rail-based metro systems costing between US\$50 million and US\$320 million per kilometre (Planning and Implementation of a Bus Rapid Transit System in Latin America: Summary Aimed at Decision Makers, 2010). However, rail-based systems can transport greater numbers of people, although the TransMilenio in Bogotá claims to move about 40,000 people per hour and direction. The low-cost and convenient infrastructure requirements allows BRT systems to develop a large network around a city that puts more and more people in walking distance of a transit corridor. Low costs make the system accessible to the poor and make possible financial sustainability in such a way that the system not require government subsidies or external grants to support its running.

Traffic accidents mean a significant cost to society in terms of medical treatment and lost lives. In the case of TransMilenio, a comparison of statistics before and after system implementation indicates an important reduction in the number of accidents in the system corridors for 1999 and 2001. According to Sandoval (2002), the Transport and Transit Secretariat of Bogotá (STT) and Metropolitan Police Department have reported a $92 \%$ reduction in fatalities and a $75 \%$ reduction in injuries resulting from traffic accidents, as well as a $79 \%$ reduction in collisions for that period.

The Latin American experience shows that BRT is attractive to urban travellers since it reduces journey time while at the same time providing high-capacity services. The fact that BRT systems provide distinctive, frequent but limited stop services, generally operating on roads with transit priority at traffic lights, makes it faster and more efficient. BRT systems also offer increased safety for passengers in waiting areas. For instance, in the case of Curitiba these areas are tubes, and in many cases waiting areas are roofed and strengthened with more powerful public lighting. It has also been observed that this safety effectiveness has encouraged those with higher incomes to start using the public transport system in Curitiba. BRT systems offer opportunities for public-private partnerships which are specially needed for transport reforms. Regulation (by local authorities) and investment (by private companies) need to go hand in hand to effectively achieve the goals of adopting BRT under a wider program of public transport reforms. For example, Bogotá has dramatically reformed its controls on parking; on-street parking has been eliminated from many streets, which have been converted instead into attractive public spaces. Likewise, Curitiba has dramatically improved its allocation of public space to pedestrians and commercial areas, with major car-free areas in the city centre. The pedestrian zones also act as feeder services to the BRT system by easing pedestrian movements in the immediate vicinity of stations. This would most likely have been more difficult to implement without private-sector involvement, which is also crucial for the proper functioning of BRT systems. Although publicly operated bus authorities continue to exist in Latin America's mega-cities, they are rapidly losing passengers to private formal and informal transit operators. In most developing country cities, bus operations are now entirely in private hands. In Quito, Bogotá and Curitiba, bus operators were fully incorporated into the planning from the very beginning.

The successful experiences of Curitiba and Bogotá have been a reference point and are widely discussed elsewhere. Therefore, this paper will focus on two new BRT experiences involving Mexico City and Ahmedabad in India.

\section{Economic, social and environmental indicators}


Sustainable development has been generally translated (e.g., under CDM) into changes in economic, social, and environmental development (Olsen \& Fenhann, 2008). Specifically for transport, a similar classification has been followed (e.g., see Litman, 2007; Haghshenas et. al., 2012). The broad themes of economic, social, and environmental development are generally further divided to specific indicators. Economic aspects refer to, for instance, increased welfare due to more efficient transport modes with less time spent on travelling and increased potential hours at work as result. Benefits like increased accessibility to working and education places, and decreased number of accidents being another example. Although social aspects are given less attention, many of the benefits will have impacts on the economy as well. Some of these are gender and age equity (accessibility for women and the elderly alike), puberty reduction (due to improved access to work, education and healthcare) and general wellbeing (due to safer transport conditions). When it comes to environmental aspects; the level of local emissions as well as global emissions (CO2 emissions) are the ones most commonly considered. It is along these aspects that the BRT systems of the two cities described in this paper are analysed.

\section{The case of Metrobus in Mexico City}

Mexico City's Metrobus is the largest BRT system in Mexico. Operated by five lines, it covers $105 \mathrm{~km}$ of roadways and serves approximately 850,000 passengers a day (METROBUS, 2013). It was launched in 2005 and in 2013 received the Sustainable Transport Award from the Institute for Transportation and Development Policy. Metrobus is one of several BRT systems running in Mexico, which makes the country to one of twelve Latin American countries with more than one running BRT system. Ten more cities in the country introduced this transport modality after the launching of Metrobus, nine more are currently under construction and two are in the planning phase. Metrobus is well-connected with public buses, which transport 12 million passengers per day, and with the subway, which transports 4.4 million passengers per day (STC, SETRAVI, 2013). All this makes Mexico City's transport system one of the most affluent in the region.

Metrobus was one of the first public transportation projects in the world to be granted the ability to offset credits for greenhouse gas emissions. Supported by the Global Environmental Facility (through the World Bank), the development of a methodology to demonstrate environmental additionality ${ }^{6}$ and thus become eligible for the United Nation's Clean Development Mechanism was initiated. The validation process started in 2004, when an initial measurement methodology (CDM-NM0158) was proposed. After rejection, the methodology was modified and presented again in February 2008 (CDM-NM0258). It was officially approved in September 2009, and the Insurgentes corridor was registered as a CDM project. The other corridors are currently under registration, and those being planned have been pre-registered. This could make Metrobus one of the largest CDM public-transport projects in Latin America in the years to come.

\footnotetext{
${ }^{6}$ Although there is a debate about whether additionality should be a criterion for the CDM implementation process or not, there are still different ways of interpreting and operationalising this notion (Müller, 2009). Nevertheless, additionality is here understood as stated in Article 12 Section 5 of the Kyoto Protocol: "emission reductions resulting from each project activity shall be certified by operational entities to be designated by the Conference of the Parties serving as the meeting of the Parties to [this] Protocol, on the basis of (...) reductions in emissions that are additional to any that would occur in the absence of the certified project activity”. Cf. UNFCCC Kyoto Protocol, accessible at < http://unfccc.int/resource/docs/convkp/kpeng.pdf>
} 
The Metrobus project was from its inception closely aligned with the country's National Development Plan (Plan Nacional de Desarrollo, PND) and with Mexico City’s General Development Program 20132018. One of the main features of the BRT system is its management model involving all the stakeholders that participated in the planning of Metrobus from the beginning. It is thus a good example of privatepublic partnership. The Metrobus management model has three main features: 1) a public decentralized unit called Metrobus representing the local authorities; 2) a new structure where private transport companies will operate the routes; and 3) trust funds where private companies collect the fares and provide payment services to the transport companies (METROBUS, 2013). The management model also includes climate policy and emission reductions as cross-cutting elements in its administrative structure through a Planning and Evaluation Direction that reports directly to the Metrobus General Direction, which monitors compliance with the emission reduction goals (GDF, 2011: 64).

As mentioned above, Metrobus was planned and implemented using a participatory approach involving all relevant stakeholders from the beginning, which may have been the key to its success. Several civilsociety organizations and non-governmental organizations (NGOs) were invited to participate in the development of the project, with Sustainable Transport Centre (CTS) EMBARQ standing out.

\subsection{The Economic, Social and Environmental Benefits}

Although the main driving force for the implementation of Mexico City's BRT system was the high level of pollutants from the transport sector, its implementation has significantly benefited the economy and society too, with improved health, increased mobility, less time spent travelling and increased gender equality being the most important outcomes.

Prior to the launch of the Metrobus Insurgentes corridor, a trip from Indios Verdes to El Caminero (the northernmost and southernmost terminals of Line 1) took 2 hours and 40 minutes; the same trip with Metrobus takes 1 hour and 23 minutes, which is a decrease of nearly 50\% (Voukas, 2012). Travel time reductions have been similar for subsequent lines, with reductions of over 50\% for Lines 2 and 3 (Voukas, 2012 - in OCDE-CTS, 2012). According to a study undertaken by the University Program of City Studies, Metrobus has contributed to a significant improvement in the quality of life of Mexico City's inhabitants, which to a large extent can be attributed to less time spent travelling. Another significant improvement is the spread of transport modal distribution in the urban context. ${ }^{7}$ Average bus running speeds were also doubled from $10 \mathrm{~km} / \mathrm{h}$ to $20 \mathrm{~km} / \mathrm{h}$ in the Insurgentes corridor (ITDP, 2012).

Nevertheless, Mexico City's has not yet achieved its full potential, and its share of modal distribution can still be increased. According to the Secretary of Transport and Roads (SETRAVI), minibuses and combis

\footnotetext{
${ }^{7}$ From 1994 to 2007, the average travel time was raised from 46.9 to 53.2 minutes. Generally speaking, both public and private vehicles reduced their speed and raised the average time for traveling the same distance. Nevertheless, this change was even more notorious for private transport. By 2007, there was no difference in travel speeds, even when the distances covered by public transport were increased. This could be explained because of factors such as traffic jams and the reduced capacity of public transport options such as subways. Cf. Programa Universitario de Estudios sobre la Ciudad (PUEC), Evaluación del diseño $e$ instrumentación de la política de transporte público colectivo de pasajeros del Distrito Federal. National Autonomous University of Mexico, Mexico, p. 31.
} 
stood for the main mode of transportation in 2010, representing around $45 \%$ of the total in the city (See Figure 1).

Figure 1

Modal distribution for the Mexico City Metropolitan Area 1986-2007

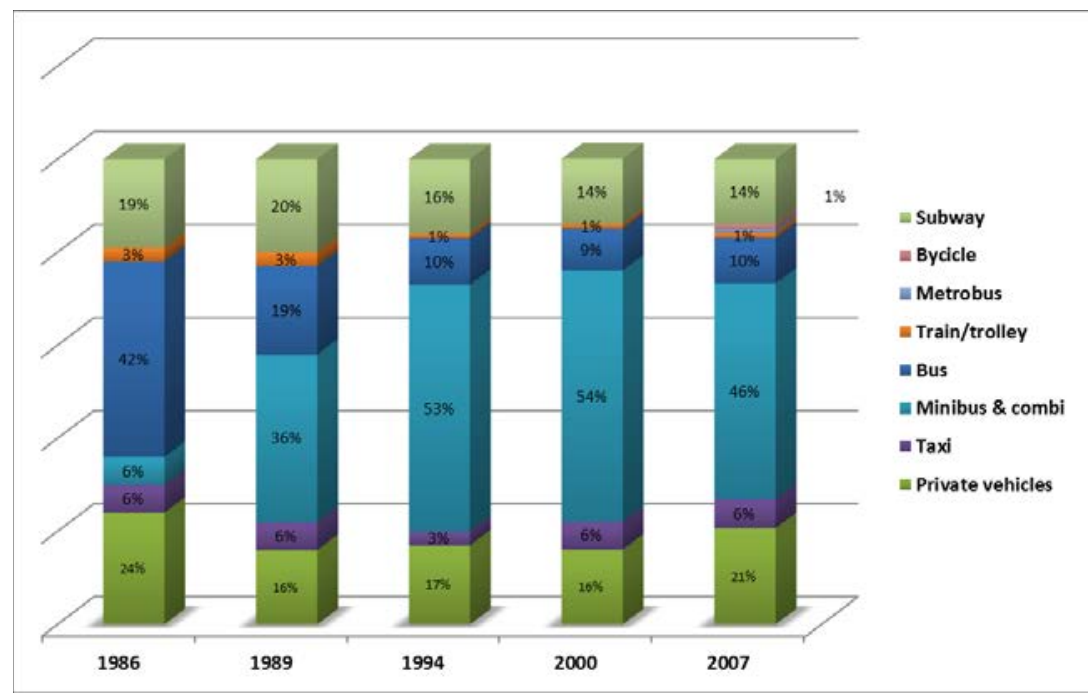

Source: Integral Program for Transport and Roads (Programa Integral de Transporte y Vialidad del Distrito Federal) p. 41

In addition to reductions in times spent on travelling, Mexico City's BRT opened the doors to renewed intermodal changes. Along with Metrobus, new programs encouraging the use of bicycles (Ecobici program) and new subway lines have been added. A proposal for ten new BRT lines for the period 20132018 is included in the Master Plan for network expansion. The plan is to have $277 \mathrm{~km}$ of BRT roadways by the end of this period, with a service radio of $2 \mathrm{~km}$ per station, serving 2 million passengers per day, and an estimated 30\% reduction in traffic accidents (ITDP, 2012). Furthermore, ITDP Mexico presented an 18 lines network expansion program in April 2014, which will add 334 km to the network by 2024. ITDP (2014).

Enhanced the conditions for gender equality is another benefit of the BRT system. The fact that the city's administration has adopted a gender cross-cutting approach for public policy design has encouraged the Metrobus administration to incorporate gender-oriented measures into its operation and administration practices. Currently, 57\% of Metrobus users are women (Metrobus, 2012), clearly resulting from a link between transport and gender policy generated by several planning actions, such as the General Program for Equality of Opportunity and No Discrimination for Women,

The main roads where Metrobus runs saw a change in its layout, with a more organized urban design and intermodal accessibility. The fact that Metrobus runs in dedicated lanes reduces the motorways confined to private vehicles. New inter-modal transfer centres and connections to subway stations, cycle stations, electric buses and suburban trains were also created, thus providing new facilities to make public transport connections easier. Recently, the new Line 5 introduced the concept of a complete street, which aims to achieve a balance between walking and cycling ways, roadways and BRT dedicated lanes. This 
will in turn promote a better urban and sustainable allocation, as well as the coexistence of several urban mobility modes in the same space for pedestrians, cyclists, public transport users and private vehicles (ITDP, 2013).

\subsection{Emission reductions}

As mentioned earlier, the main goal of the implementation of Metrobus was the reduction of per-million suspended particles, pollutants which affect public health severely. As Voukas indicates, the initial project retook elements from earlier reports on individual exposure to transport-related pollutants (both public and private) published during the 1990s. The Reports showed that individual exposure to carbon monoxide in transport may have been surpassing the World Health Organization's recommendations. In 2002 individual average exposition of 13 and $18 \mathrm{ppm}$ for CO, 78 and $84 \mu \mathrm{g} / \mathrm{m} 3$ for PM2.5, and $7 \& 8$ ppbv for benzene was found in buses and minibuses respectively. For organic volatile compounds, toluene levels of 153, 130, 110 and $63 \mathrm{ug} / \mathrm{m} 3$ were found in private cars, micro-buses, buses and the subway respectively. For the same substances and in the same order, levels of formaldehyde of 25.2, 40.2, 24.7 and $19.4 \mathrm{ug} / \mathrm{m} 3$ were found. ${ }^{8}$

According to Garcia, emissions from Metrobus (gram/km per passenger) were reduced ninefold between 2004 and 2011 compared to buses and minibuses. Similarly, carbon monoxide levels from Metrobus were significantly lower than those from buses and minibuses. Emissions of PM2.5 micro-particles ${ }^{9}$ from Metrobus were 35\% lower than those from minibuses and 23\% lower than emissions from conventional buses (Garcia, 2011). Decreased exposure to pollutants has a direct positive effect on health and consequently on productivity. As CTS EMBARQ reported, two thousand regular users of Metrobus Line 3 were prevented from attending work in 2012 due to respiratory illnesses. If this trend is maintained, additional benefits will be observed in twenty years from now. For instance, bronchitis and other respiratory diseases could be reduced at an estimated cost of 4.5 million dollars (CTS EMBARQ, 2013).

During its first six years of operation, Metrobus Line 1 was able to reduce $\mathrm{CO}_{2}$ equivalent emissions by 300,000 metric tons, corresponding to US\$800,000 of income for the city through the CDM mechanism (NYC Global Partners, 2012). Although Line 1 is currently the only line of the network that has been registered to the CDM, the emissions from the other lines are also being measured. By 2011, the first three lines together reached reduction levels of 100,000 $\mathrm{TonCO}_{2} \mathrm{eq} /$ year (Garcia, 2011), (see Table 1).

The general equation for the calculation of emissions reductions consists of a simple algorithm. The grand total for emissions reduced results from the balance between the generated and reduced emissions (Metrobus, 2011: 23). The starting point is the baseline calculated in 2004 before the construction of Line

\footnotetext{
${ }^{8}$ Cf. Voukas, 2012, in Evaluación de los beneficios en la exposición personal de pasajeros por la instrumentación de cambios en el transporte público. Instituto Nacional de Ecología-Centro de Transporte Sustentable (2006), Mexico, pp. 4-5.

${ }^{9}$ PMs are the measuring unit for micro-particles suspended in the air. The subscripted number indicates the particle's diameter, with sizes ranging from atomic sizes to a human hair gross. The international variation ratio goes from 0.005 to 10 micras of aerodynamic diameter. Because of its size, PM2.5 stay longer suspended in the air and can travel far beyond the PM10, which are potential threats to public health. Cf. Instituto Nacional de Ecología (2007), Tercer almanaque de datos y tendencias de la calidad del aire en nueve ciudades mexicanas. INE, México.
} 
1 (Insurgentes corridor) and is the same for each line (measurements should be made before the line is constructed). After the project results have been calculated, risks are deducted from the balance. Risks are those elements that constitute emissions increases, such as the bouncing effect, ${ }^{10}$ prohibitions of left turns and the destruction of old, inefficient units (Garcia, 2011).

Table 1. Emission reductions by corridor 2005-2011 ( $\left.\mathrm{TonCO}_{2} \mathrm{eq}\right)$

\begin{tabular}{ccccccccc}
\hline & $\mathbf{2 0 0 5}$ & $\mathbf{2 0 0 6}$ & $\mathbf{2 0 0 7}$ & $\mathbf{2 0 0 8}$ & $\mathbf{2 0 0 9}$ & $\mathbf{2 0 1 0}$ & $\mathbf{2 0 1 1}$ & TOTAL \\
\hline $\begin{array}{c}\text { Insurgentes } \\
\text { Norte }\end{array}$ & 15,804 & 30,683 & 38,487 & 40,699 & 44,492 & 44,119 & 14,575 & 228,858 \\
$\begin{array}{c}\text { Insurgentes } \\
\text { Sur }\end{array}$ & - & - & - & 7591 & 9617 & 9627 & 3206 & 30041 \\
$\quad$ Eje 4 sur & - & - & - & 7804 & 18,727 & 18,977 & 6,387 & 44,091 \\
$\quad$ Total & 15804 & 30,683 & 38,487 & 49,069 & 72,836 & 72,724 & 24,168 & 302,989
\end{tabular}

Source: García, 2011. *Emissions until April ** Emissions commercialized to the Spanish Carbon Fund *** Emissions reduced from March 13th $* * * *$ Emissions reduced from December the $16^{\text {th }}$.

Emissions reductions have been high due to the fact that the first corridor was introduced in one of the most congested avenues of Mexico City (it crosses the whole city from north to south), crossing industrial, residential and major commercial zones. The positive effects due to less time spent on travelling and the improvements in public health are also relevant and have helped to promote the BRT in other areas of the city.

The benefits of the BRT experience in Mexico City demonstrate that it is possible to articulate a sustainable transport policy linked to other development dimensions and urban planning. Metrobus was the result of a clear environmental concern (air quality) that gave rise to co-benefits like improved health and increased mobility. As additional Metrobus lines are planned, its coordination with urban planning and social participation will continue to be the main challenge.

\section{Experience from Asia: the case of Ahmedabad}

In India a total of ten BRT projects have been implemented or are currently under implementation. Ahmedabad has the largest BRT network to be built so far and is considered a success by external observers. The project was given the Sustainable Transport Award for 2010 by ITDP. ${ }^{11}$ It is for these reasons we have decided to take a closer look at this BRT experience from India.

\footnotetext{
10 The bouncing effect refers to the increased demand for transport services due to reductions in cost, time or modality. In the case of the BRT, the effect could mean that more people are using the system because it helps to reduce the time for or cost of transport, or because the old routes no longer exist.

11 http://www.itdp.org/get-involved/sustainable-transport-award/previous-award-recipients/ahmedabad-india, accessed 30 April 2012.
} 
Table 2. $\quad$ Approved BRT projects in India as of 2011

\begin{tabular}{clccc}
\hline S.no. & City & $\begin{array}{c}\text { Approved } \\
\text { kms }\end{array}$ & $\begin{array}{c}\text { Approved cost } \\
\text { (2007 million } \\
\text { US \$) }\end{array}$ & $\begin{array}{c}\text { Per km cost } \\
\text { (million US \$) }\end{array}$ \\
\hline 1 & Ahmedabad & 88.5 & 238 & 2.69 \\
2 & Rajkot & 29 & 27 & 0.92 \\
3 & Surat & 29.9 & 114 & 3.81 \\
4 & Bhopal & 21.71 & 58 & 2.65 \\
5 & Indore & 11.45 & 24 & 2.09 \\
6 & Pune \& Pimpri & 124.77 & 331 & 2.65 \\
7 & Chinchwad & & & 2.39 \\
8 & Vijaywada & 15.5 & 37 & 2.57 \\
9 & Vizag & 42.8 & 110 & 2.04 \\
10 & Jaipur & 26.1 & 53 & 2.62 \\
\hline & Delhi & 14.2 & 37 & \\
\hline
\end{tabular}

Source: Mahadevia et al. (2012) and MOUD (2008).

Ahmedabad BRT was conceived in 2005 by the Ahmedabad Municipal Corporation. The BRT was seen as a means of putting in place properly laid out roads and creating road space for pedestrians and cyclists. The design philosophy is based on connecting busy places of the city but avoiding busy roads: for example, the first corridor was on a road with a width of $40 \mathrm{~m}$ and manageable traffic volumes of 30006000 PCU's along most stretches and of 6000-9000 PCUs along a few stretches. When the federal government conceived a mission for urban renewal for cities under the Jawaharlal Nehru Urban Renewal Mission (JnNURM) in 2005, Ahmedabad quickly grabbed the opportunity and submitted a detailed project report for a BRT to the federal government. This was the first proposal for BRT under JnNURM and was approved in 2006. The federal government supports the projects to the extent of 35\% of project costs, with an additional 15\% coming from the state government and another $50 \%$ from the municipal authority, in case of Ahmedabad the Ahmedabad Municipal Corporation (AMC).

The construction work for the project started in 2007. The project has a first phase of $58.3 \mathrm{~km}$, of which $44.5 \mathrm{~km}$ have been completed. The first corridor of $12.5 \mathrm{~km}$ was opened for operations in October 2009. As mentioned earlier, a non-busy road was selected as the first corridor to generate positive image in the minds of the vocal middle classes. Low traffic also helped in managing construction and in reducing the disruption to the existing road users. With the goodwill thus generated, the authorities began social marketing of the project. In the second phase, the BRT system is venturing on to busier inner-city roads with perpetual road congestion.

Des pite its recent introduction, the project has already received accolades from international agencies (ITDP), as well as awards within India for being the best mass transit project under JnNURM. This has helped in further social marketing of the project. The project has also received political support from the state's chief minister and local authorities. The project has been implemented professionally and it is one of the few BRT projects in India which is adding passengers and also expanding corridors. 
In this paper a summary evaluation using the indicator framework developed by Tiwari et al., 2011 is presented. The assessment relies on the results of a user survey carried by CEPT University (Mahadevia et al., 2012) and other secondary literature. The survey revealed that a typical user of BRT was male and of middle income because $72.5 \%$ of respondents turned out to be male with $75 \%$ having a monthly income of between US\$ 120 to 8000. Three quarters of users were young, within the age range of 15 and 40 , and work and education were the reasons for travel for around $66 \%$ of users. Three-quarters of users were salaried employees. An overwhelming number of respondents were living close (less than $1 \mathrm{~km}$ ) to the BRT corridor, and therefore walking was the most used mode of reaching BRT stations, though Ahmedabad Municipal Transport System (AMTS) ${ }^{12}$ buses and paratransit were also used by respondents. About 30\% of trips on BRTS are for purposes related to social, recreational and shopping trips, and only $42 \%$ of users used BRTS for more than twenty days a month, which means that the BRTS still has to find regular and sustained ridership in the city. BRT has encouraged new demand and enhanced the mobility of some people in the city but has failed to develop dedicated commuters who use the system for workrelated reasons every day. As already mentioned, it is mainly middle-income groups, not low-income groups (with incomes less than Rs. 10,000 per month) (Mahadevia et. al. 2012) that use Ahmedabad BRT, and many of them were previously public transit users commuting longer distances.

\subsection{Economic, social and Environmental Benefits}

Mobility and accessibility. The project intervention has brought changes to public transport provisioning in Ahmedabad and thus had an impact on choices of mode of transport, travel times and spending on transport for users. The BRT has led to modal shifts in the direction of public transport. In a survey carried by Mahadevia et al. (2012) it was found that $47 \%$ of BRT users are from the municipal bus system which ran along the BRT corridors prior to the BRT, another 25\% had shifted from auto rickshaws, $2.3 \%$ from walking and cycling, $11.7 \%$ from private motorised vehicles and $13 \%$ had been encouraged to travel because of the BRT. The BRT has improved choices for NMT users (walking /cycling), paratransit (autorickshaws) and private motorised transport users. For NMT users the improved mobility has meant increased costs. However, for other users there have been substantial cost savings - for users of the existing bus system of 7.9\%, for auto-rickshaw users $42.1 \%$ (shared) and $83.1 \%$ (individual), private twowheelers 66.4\% and four-wheelers 89.1\% (Mahadevia et. al., 2012). Besides the reduced costs, users have also been benefited from reduced journey times, as the average speed on the BRT corridor during peak hours was $25 \mathrm{~km}$ per hour as compared to an average speed of $15 \mathrm{~km}$ per hour for AMTS buses (Bajracharya, 2008). The time savings are even higher, as the waiting time for BRTS buses is much lower.

The project has made a contribution to public transport and in improving mobility. The BRT system carried 140,000 trips ${ }^{13}$ every day in 2011. Using an average trip length of $8.7 \mathrm{~km}$ (Mahadevia et. al. 2012) the BRT catered to around 440 million passenger $/ \mathrm{km}$ in a year. This is a very small proportion of the motorised trips for Ahmedabad: for example, in 2005 passenger transport demand was estimated at 21 billion passenger/km (Shukla et. al., 2009). Ahmedabad has witnessed a rapid growth in cars and two-

\footnotetext{
12 This is the earlier public transit system, and it exists in parallel to the new BRT system, itself a criticism of it.

${ }^{13}$ http://www.itdp.org/news/ahmedabads-janmarg-wins-national-award-for-best-intelligent-transport-system, accessed 5 November 2012.
} 
wheelers in the last few years, and passenger demand can be easily assumed to have been around 30 billion passenger $\mathrm{km}$ for 2011, which means that the BRT is contributing to less than $1 \%$ of mobility demand. The limited role the BRT is currently playing can also be validated from a survey of its users. An overwhelming percentage of users were those living within $1 \mathrm{~km}$ of the BRT corridor. This is because it has not been integrated with the rest of the transport system being run by AMTS (Mahadevia et al., 2012).

There is an issue with regard to the gender inclusiveness of the BRT system in Ahmedabad. There is a great gender divide in the users of BRT, and women continue to have restricted mobility in the city, as only one third of trips are made by women in Ahmedabad (IPTS 2000). Mahadevia et al. (2012) found that only 27 per cent of BRT users in the city were women. The BRT is not very popular among lower income groups. Three low-income settlements located along the BRT corridors were studied, and it was revealed that only $3 \%$ of trips were being made using BRT by low-income residents. The higher fares of the BRT compared to the regular (municipal) bus service, the AMTS, may provide one explanation, besides the coverage of the system. BRT fares were increased twice after this study was conducted, and this might have had a further impact on use of the system by low-income groups in general and women within them in particular.

There is another contentious issue in Ahmedabad regarding the sharing of the road space. Footpaths and cycle tracks have not been designed and built along all corridors, thus compromising safety and access of the pedestrians and cyclists. Only $26 \%$ of the operational corridor has provision for segregated cycle tracks, in contrast to the Latin American examples. Even when cycle tracks and footpaths are provided along the BRT corridor, there are issues with the design and maintenance of the non-motorized infrastructure.

\subsection{BRT and Carbon Emissions}

The BRT system has attracted passengers away from AMTS buses, auto rickshaws, private vehicles, etc. and also encouraged some trips which otherwise would not have been made (Mahadevia et al., 2012). We combined this information with vehicle emission coefficients and found that the BRT system has 17\% lower emissions from a BAU case (see Table 3).

Table $3 \mathrm{CO}_{2}$ Emissions Reductions due to BRT

\begin{tabular}{lcccc}
\hline \multicolumn{1}{c}{ Mode } & $\begin{array}{c}\text { Pre BRT } \\
\text { demand } \\
\text { (million } \\
\mathrm{PKM})\end{array}$ & $\begin{array}{c}\mathrm{CO}_{2} \\
\text { emissions } \\
++(\mathrm{tC})\end{array}$ & $\begin{array}{c}\mathrm{BRT} \\
\text { demand } \\
\text { (million PKM) }\end{array}$ & $\begin{array}{c}\mathrm{CO}_{2} \\
\text { emissions }++ \\
(\mathrm{tC})\end{array}$ \\
\hline 1. AMTS Bus User & 206.8 & 2,846 & 0 & 0 \\
\hline 2. Auto User Individual & 57.64 & 1,617 & 0 & 0 \\
\hline 3. Auto User Shared & 56.76 & 1,061 & 0 & 0 \\
\hline 4. Walking \& Cycling & 10.12 & & 0 & 0 \\
\hline 5. Motorised 2 wheeler & 44.88 & 1,596 & 0 & 0 \\
\hline 6. Motorised 4 wheeler & 6.6 & 655 & 0 & 0 \\
\hline 7. BRT Bus & & & 440 & 6,445 \\
\hline
\end{tabular}




\begin{tabular}{|c|c|c|c|c|}
\hline \multicolumn{2}{|l|}{ Induced trip } & \multicolumn{3}{|c|}{57.2} \\
\hline \multicolumn{2}{|l|}{ Pre BRT Demand } & \multicolumn{3}{|c|}{382.8} \\
\hline Total & 382.8 & 7,775 & 440 & 6,445 \\
\hline Therefore Savings & & 1,330 & & \\
\hline \% Reduction & & $17 \%$ & & \\
\hline \multicolumn{5}{|c|}{ ++ C Emissions calculated using the following assumptions for vehicle efficiencies } \\
\hline 2 Wheeler & 35.6 & tonnes/mpkm & & \\
\hline 3 Wheeler CNG - Individual & 28.1 & tonnes/mpkm & & \\
\hline 3 Wheeler CNG - Shared & 18.7 & tonnes/mpkm & & \\
\hline 4 Wheeler MS & 99.2 & tonnes/mpkm & & \\
\hline Bus Diesel & 14.6 & tonnes/mpkm & & \\
\hline Bus CNG & 13.8 & tonnes/mpkm & & \\
\hline
\end{tabular}

The emission reductions are, however, quite low in aggregate terms (1330 tC) because the overall impact of BRT on Ahmedabad's transportation needs is currently limited. Secondly, the shift to BRT has been mainly of public transport users for whom emissions rates were any way low. Therefore, if a major shift in emissions is to be achieved, then BRT must become an alternative for a majority of personal transport users.

\section{Conclusions}

A number of aspects need to be taken into consideration for a successful BRT implementation. The most important is a need to have a citywide transport plan, which is integrated not only with the current landuse plan, but also with future land-use and development plans. Transport should be holistically approached, and where this has been done, as in case of Mexico City and Ahmedabad, the BRT was an outcome of housing planning rather than of transport planning.

The second aspect is to have a participatory approach involving relevant stakeholders from the very beginning of the planning process. Although key stakeholders were involved in the case of Metrobus, they may have been involved late in the process thus delaying its implementation. This argument could be supported by the fact that one of the main difficulties for Mexico's City authorities was to negotiate and involve the former "microbus" drivers and leaders into the new already designed scheme of the routes affected, which indicate a late stakeholder involvement. Therefore, involving key stakeholders from the very beginning of the planning phase may have prevented the delay. Nevertheless and despite a late involvement, their involvement has proved to be fundamental for the acceptance and participation of the new transport system in the case of Mexico City, where the authorities developed a new management scheme that included all stakeholders in the initial negotiations and further active participation as concessionaires, NGOs, and the private sector. This made it possible to meet the needs of potential users,

\footnotetext{
14 'Finally, CNG buses for BRTS arrive in Ahmedabad, to roll out in a week':" http://www.dnaindia.com/india/report_finallycng-buses-for-brts-arrive-in-ahmedabad-to-roll-out-in-a-week_1563566 accessed 5th November 2012.
} 
but it contributed significantly to increasing the sense of ownership among stakeholders, which is otherwise difficult to obtain.

Post Metrobus implementation there are still a series of challenges to be faced. According to reports issued by the Metrobus authorities, the three main challenges for Metrobus are: 1) a clearer methodology for measuring GHG reductions; 2) a multidimensional planning scheme that could take into consideration relevant areas related to the administration and operation of BRT, i.e. health, security and environment and; 3) the assurance of the right transport mode, through a clearer methodology and renewed figures on the impact that the BRT system can have on mobility patterns and behaviour in Mexico's City transport users.

Gradual changes in passengers' habits are also very important when introducing new transportation systems. Changes overnight have proved to make the difference between success and failure. There is evidence that restructuring changes have a greater likelihood of being accepted by users if they are introduced gradually. Metrobus constitutes a good example of an implementation which took place gradually. The Ahmedabad BRT system started with a pilot corridor which caused least inconvenience to road users so that negative publicity is not generated by the project at the initial stages. The pilot corridor introduced people to the concept of a BRT, and therefore subsequent corridors became much easier to handle politically.

A high level of political will is another key element in this context. This applies to both Ahmedabad, where, despite the lack of a Comprehensive Mobility Plan (CMP), the city was far ahead in terms of public transport planning, as a BRT system had been conceived long before the existence of a federal program supporting such initiatives. The state's Chief Minister was quite supportive, and state government support to funding the project was also quickly provided. Similarly, in 2007 in Mexico City, the local government (Gobierno del Distrito Federal) developed a new strategic sustainability plan known as "Plan Verde", which already included a mobility urban plan strategic objective for the capital.

Well-planned BRT systems have proved to be the right option in a number of cities worldwide, though varying degrees of success. Both cities discussed here are considered to have succeeded in the implementation of their BRT systems and have been awarded international recognition. The Ahmedabad BRT is still in a nascent stage and meets only $1 \%$ of travel demand; it therefore needs to be integrated with other modes of transport to achieve a significant impact on the city. Metrobus has still to refine its emission measurement methodologies and find inter-institutional coordination to share its experience with other cities in the country.

An examination of BRT projects in terms of their economic and social impacts is also important. The Ahmedabad BRT seems to have limited utility for these sections, and therefore how BRT systems can be made more inclusive needs to be examined. In spite of a lot of rhetoric about the inclusion of the socially and economically weaker sections of society in the detailed project reports of the Ahmedabad BRT, this has not been translated into reality. The ridership of women is only $27 \%$, which is even lower than share of trips made by women in the bus system, and same is true for people from low-income groups in society.

The fact that a BRT system can be implemented at a fraction of the cost of other MRT systems like light rail trains or metros and yet meet the transportation needs of the population in a safe and comfortable way makes it an attractive option. The BRT systems of Curitiba in Brazil and Transmilenio in Bogotá in 
Colombia have served as a source of inspiration. After their introduction, similar BRT systems have been replicated around the world with more or less success. These two systems have at least kept in mind the needs of low-income households in planning their systems. The comprehensive planning approach to the BRT system places equity at the forefront of the design of the system, thus creating inclusive sustainable transport systems in developing countries.

BRT systems emerge as a valid option for the mitigation of $\mathrm{CO}_{2}$ emissions, as has been validated by these two case studies. The scale of emissions reductions has been modest in the case of Ahmedabad, as BRT riders have mainly come from the existing bus system, from auto rickshaws for which emission rates are already low, and also the BRT itself is at a nascent stage. The emission reductions in the case of Metrobus have also been modest, though CDM validation for the project has helped monetize these reductions, and a revenue of around US\$ 800,000 was accrued to the city in six years. However, the CDM revenues are insignificant compared to the scale of the project. Overall $\mathrm{CO}_{2}$ mitigation can be seen as a co-benefit of the BRT. 


\section{References}

Amy J Gardner, Journalist. May 15, 2011

Bajracharya, Ashim Ratna (2008), The impact of modal shift on the transport ecological footprint: a case study of the proposed Bus Rapid Transit System in Ahmedabad, India, Downloaded on May 3, 2012 <http://www.itc.nl/library/papers_2008/msc/upm/bajracharya.pdf>.

Carrigan, A. and King, R, . Et.al. (2013): Social, Environmental and Economic impacts of BRT systems, Bus Rapid Transit Case Studies from Around the World. EMBARQ- World Resources Institute. USA.

Dalkman H., Sterk W., Bongardt D., Wittneben B. and Baatz Ch. (2007): The Sectoral Clean Development Mechanism: A Contribution from a Sustainable Transport Perspective, JIKO Policy Paper, Wuppertal Institute for Climate, Environment and Energy.

Economic Commission for Latin America and the Caribbean (2012): Statistical Yearbook for Latin America and the Caribbean. ECLAC-United Nations. Chile.

Francke, E. Macías, J. and Schmid, F. (2012): Mobilising Private Investment for Bus Rapid Transit Systems: The case of Metrobus, Mexico City. México, OECD-CTS EMBARQ Mexico.

García, Gonzalo (2011): Untitled presentation on Metrobus to the Clean Air Institute. Metrobus. México. Accessible at < www.cleanairinstitute.org/download/rosario/gp3_4_03_gonzalo_garcia.pdf>

George, Clive, 1999. Testing for sustainable development through environmental assessment. Environmental Impact Assessment Review, 19(2), 175-200.

Gobierno del Distrito Federal (2011): Aviso por el cual se da a conocer el Manual Administrativo en la parte orgánica del Organismo Público Descentralizado Metrobus, at Gaceta Oficial del Distrito Federal, May 24th, 2011. Mexico.

Gobierno del Distrito Federal (2013): Acuerdo por el que se aprueba el Programa General de Desarrollo del Distrito Federal 2013-2018, at Gaceta Oficial del Distrito Federal, September 11th, 2013. Mexico.

Haghshenas H. and Vaziri M (2012) Urban sustainable transportation indicators for global comparison. Ecological Indicators 15:115-121

Hector Riveros Rotgé (2009). Análisis del programa “Hoy No Circula”. Ciencia, México, January-March, pp. 76-83.

IEA, 2011. IEA Statistics, 2011 Edition

Instituto Nacional de Ecología (2007): Tercer almanaque de datos y tendencias de la calidad del aire en nueve ciudades mexicanas. INE. México.

Instituto Nacional de Ecología. Centro de Transporte Sustentable. (2006), Evaluación de los beneficios en la exposición personal de pasajeros por la instrumentación de cambios en el transporte público. INE-CTS. 
México.ITDP (2014), Executive Summary. Proyecciones de demanda de transporte masivo en la Zona Metropolitana del Valle de México al 2024. ITDP, México.

Litman, T. (2007). Developing indicators for comprehensive and sustainable transport planning. Transportation Research Record: 10-15

Licea Viñas, Karina (2013): Primera fase: Metrobús Línea 5 Calle Completa. ITDP Mexico, Mexico.

Metrobus (2011): Reporte de Reducción de Emisiones. Reducción de Emisiones de Gases de Efecto Invernadero para el sexto año de operación del Corredor Metrobús Insurgentes. Metrobús. México.

Accessible at:

<ww.metrobus.df.gob.mx/transparencia/documentos/art15/X/X01_Informe_Reduccion_Emisiones_20092010.pdf $>$

Müller, B. (2009): Additionality in the Clean Development Mechanism. Why and What? United Kingdom. Oxford Institute for Energy Studies.

New York City Global Partners (2012): Best Practice: Metrobus Bus Rapid Transit System. NYC Global Partners' Innovation Exchange. USA. Accessible at: <www.nyc.gov/globalpartners/innovationexchange>

Olsen, K. H. and J. Fenhann (2008). "Sustainable development benefits of clean development mechanism projects: A new methodology for sustainability assessment based on text analysis of the project design documents submitted for validation." Energy Policy 36(8): 2819-2830.

Presidencia de la República (2013): Plan Nacional de Desarrollo 2013-2018. Presidencia de la República. México.

Rogat, J. Editor: Planning and implementation of a Bus Rapid Transit System in Latin America: summary aimed at decision makers. Investigaciones de Espacio, 2010.

Rogat, J,. Hinostroza, M., Ernest, K. (2009): Promoting Sustainable Transport in Latin America through Mass Transit Technologies. Colloque international Environnement et transports dans des contextes différents, Ghardaïa, Algérie, 16-18 fév. 2009. Actes, ENP ed., Alger, p. 83-92

Sandoval, E., and Hidalgo, D. (2002): TransMilenio: A High Capacity-Low Cost Bus Rapid Transit System developed for Bogotá, Colombia. Manuscript.

Secretaría de Medio Ambiente y Recursos Naturales (2009): Programa Especial de Cambio Climático 2009-2012. SEMARNAT. México.

Secretaría de Medio Ambiente, Recursos Naturales y Pesca (2002): Programa para Mejorar la Calidad del Aire de la Zona Metropolitana del Valle de México 2002-2010. SEMARNAT-Gobierno del Estado de México-Gobierno del Distrito Federal- Secretaría de Salud. México.

UN DESA. World Urbanization Prospects (2009). The 2009 Revision: Highlights, New York 2010.

Wright, L. (2002): Mass Transit Options, Sustainable Transport: A Sourcebook for Policy Makers in Developing Countries, Module 3a. Eschborn: GTZ. 


\section{Websites}

Metrobus (2103). Accessible at: <http://www.metrobus.df.gob.mx/>

Mexico City Subway (Sistema de Transporte Colectivo Metro) (2012), Operation figures, accessible at: <http://www.metro.df.gob.mx/operacion/cifrasoperacion.html>, (accessed 10 November 2013).

Mexico’s City Green Plan (Plan Verde de la Ciudad de México) (2012). Accessible at: < http://www.planverde.df.gob.mx/inicio.html>

Secretariat for Transport and Roadways (Secretaría de Transporte y Vialidades, SETRAVI). Accessible at:

$<$ http://www.setravi.df.gob.mx/wb/stv/cinco_siglos_de_transporte_en_la_ciudad_de_mexico_/rid/71?pa ge=5 $>$, (accessed 5 November, 2013) 